VÉVODA J. et al. 2013. Motivace sester a pracovní spokojenost ve zdravotnictví. 1. vyd. Praha: Grada Publishing, 2013. 160 s. ISBN 978-80-247-4732-3.

Autoři knihy Vévoda, Ivanová, Nakládalová, Bártlová, Špatenková a Prošková se dlouhodobě zabývají otázkami pracovní motivace sester, jejich bezpečného pracovního prostředí, týmové spolupráci, komunikaci a vzdělávání ve zdravotnictví. Předkládaná publikace je tak v České republice první ucelenou prací tohoto charakteru, prohlubující pohled na danou problematiku, která je v současné době aktuální a společensky žádaná.

Kniha je tvořena šesti logicky na sebe navazujícími kapitolami. První kapitola se zabývá teoriemi motivace a pracovní spokojenosti ve zdravotnictví, uvádí některé významné zahraniční a české výzkumy v této oblasti. Podrobně rozpracovává dvoufaktorovou motivační teorii Fredericka Herzberga. Druhá kapitola se zabývá týmovou spoluprací ve zdravotnictví. Zamýšlí se nad postavením sestry v multidisciplinárním týmu a uvádí předpoklady týmové práce sester a lékařù. Třetí kapitola nás přivádí $\mathrm{k}$ jednomu $\mathrm{z}$ nejdůležitějších témat, kterým je komunikace ve zdravotnictví. Zabývá se komunikačními prostředky, komunikací sestry s pacienty a komunikací sestry v týmu. Bezpečnosti pracovního prostředí se věnuje další kapitola. Seznamuje čtenáře s rizikovými faktory práce sester a jejich prevencí, s nemocemi z povolání. Pátá kapitola je věnována vzdělávání sester. Seznamuje s možnostmi kvalifikačního a specializačního vzdělávání sester. Samostatná část je věnována celoživotnímu vzdělávání sester a jeho kontrole. Stěžejní část publikace tvoří závěrečná, šestá, kapitola. Je zde předložen unikátní reprezentativní výzkum pracovních hodnot 1992 všeobecných sester (VS) pracujících v nemocnicích ČR. Sestry v něm srovnávají svůj osobní žebříček hodnost s vlastním vnímáním jeho naplnění zaměstnavatelem. Metodologicky je šetření založeno na známé Herzbergově dvoufaktorové motivační teorii, modifikované pro použití $\mathrm{v}$ pod- mínkách dnešního zdravotnictví. Ani tato dodatečná úprava však nezachycuje veškeré aspekty motivace a pracovní spokojenosti. Technikou získávání dat byl řízený strukturovaný rozhovor provedený vyškolenými tazateli. Výzkum je cenný také novým pojetím zpracování získaných dat. Mimo neparametrických testů využívá Euklidův distanční model a dataminingovou techniku rozhodovacích stromů. Výsledky výzkumu jsou prezentovány $\mathrm{v}$ šesti tabulkách a čtyřech grafech.

Knihu lze doporučit každému manažerovi ve zdravotnictví, sestrám ve vedoucích pozicích i vrcholovému managementu. Užitečné informace $\mathrm{v}$ ní naleznou také studenti škol se zdravotnickým zaměřením. Bohužel se nevěnuje některým dalším tématům $\mathrm{z}$ oblasti sociologie zdravotnictví či medicíny, např. profesionalizaci oboru ošetř̌ovatelství, psychosociální zátěži ve vazbě na výkon povolání apod. Další výhradou je absence výzkumného nástroje, který by mohl být dále využit $\mathrm{k}$ výzkumu u dalších poskytovatelů zdravotnické péče. Doporučila bych do knihy rovněž zařadit problematiku syndromu vyhoření, která s pracovní motivací velmi úzce souvisí a je stále aktuální.

Motivace a pracovní pokojenost sester je v současnoti závažným tématem, kterému je v jak v západní Evropě, tak také v USA a Kanadě věnována velká pozornost. Odchody vzdělaných a zkušených sester mimo obor znamenají pro zaměstnavatele dodatečné finančí náklady spojené s náborem nového pracovníka, ale také obtížně finančně vyčíslitelnou ztrátu v podobě snížení kvality poskytované péče. $Z$ tohoto důvodu je nezbytné, aby si manažeři na všech úrovních uvědomili, jak cenné jsou pro ně lidské zdroje a co dělat, aby předešli nadměrné fluktuaci. Tato kniha jim $\mathrm{k}$ tomu poskytuje základní návod. 
ecresms

Jifi Vévoda a kolektiv

\section{Motivace sester}

a pracovní spokojenost ve zdravotnictví

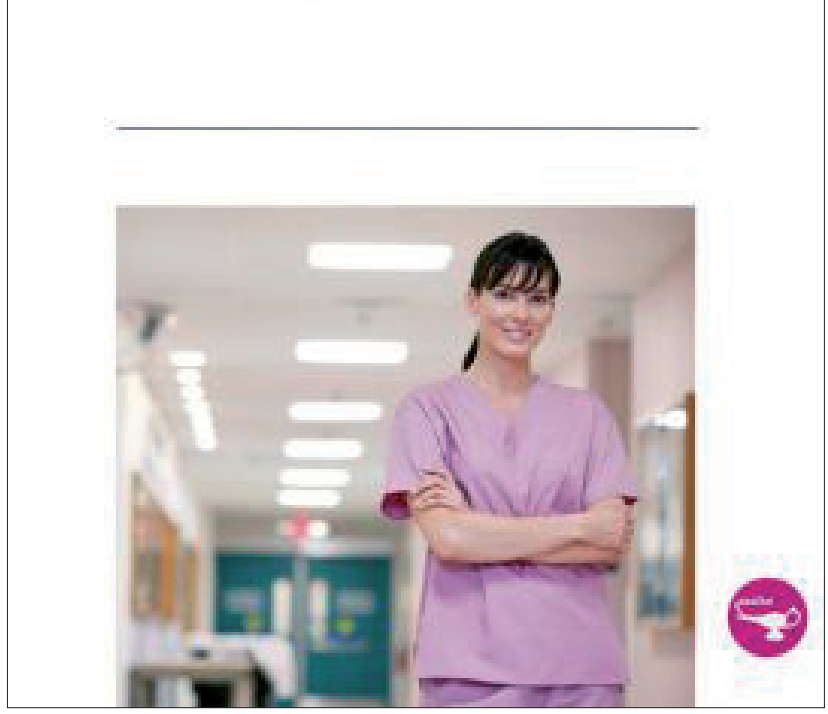

Zdroj obrázku: http://www.grada.cz/php/viewpic.php?foto=../ obalky_upr/747323.jpg\&w=270\&h=387. (cit. 2013-10-20)

\section{AUTOR RECENZE}

Mgr. Šárka Ježorská, Ph.D.

Ústav společenských a humanitních věd

Fakulta zdravotnických věd

Univerzity Palackého v Olomouci

Tř. Svobody 8

CZ-771 11 OLOMOUC

sarka.jezorska@upol.cz 